\title{
Pengembangan Perangkat Pembelajaran Matematika Berbasis Model Eliciting Activities (MEAs) untuk Meningkatkan Kemampuan Berpikir Kritis Peserta Didik SMP
}

\author{
Alhakko Latif ${ }^{1}$, Damris ${ }^{2}$, Kamid ${ }^{3}$ \\ 1, 2, 3 Program Studi Magister Pendidikan Matematika, Universitas Jambi \\ Jl. Raden Mattaher No.16 Jambi, Kota Jambi, Indonesia \\ alhakkolatif@gmail.com
}

\begin{abstract}
This study aims to produce mathematical learning tools based on the Electing Activities Model (MEAs) to improve the critical thinking skills of junior high school students that are valid, practical, and effective. The type of research used is the Plomp model of Design Research. The stages of development according to Plomp are divided into three stages in general, namely preliminary research, prototyping phase, and assessment phase. The data analysis technique carried out is related to the analysis of validity, practicality, and effectiveness. The results of the development of MEAs-based mathematics learning tools were obtained which were declared valid by experts. The average results of the RPP evaluation by experts are in a very valid interpretation, and the results of the LKPD evaluation by experts with an average interpretation are very valid. Learning tools are also declared practical based on the results of the practicality questionnaire analysis of students and teachers. Learning tools have also been declared practical. In addition to being valid, and practical, the device has also been declared effective for improving students' critical thinking skills. Classically, students' completeness increased from 33\% or 11 students to 19 students or $63 \%$. This means that the tools used are effective in improving the critical thinking skills of junior high school students
\end{abstract}

Keywords: Learning Tools, Eliciting Activities (MEAs) Models, Critical Thinking Skills

Abstrak
Penelitian ini bertujuan menghasilkan perangkat pembelajaran matematika berbasis Model Eleciting Activites (MEAs) untuk meningkatkan kemampuan berpikir kritis peserta didik SMP yang valid, praktis, dan efektif. Jenis penelitian yang digunakan adalah penelitian pengembangan (Design Research) model Plomp. Tahapan pengembangan menurut Plomp terbagi dalam tiga tahapan secara umum yaitu preliminary research, prototyphing phase, dan assessment phase. Teknik analisis data yang dilakukan terkait analisis kevalidan, kepraktisan, dan keefektivan. Hasil dari pengembangan perangkat pembelajaran matematika berbasis MEAs ini diperoleh perangkat pembelajaran yang dinyatakan valid oleh para ahli. Rata-rata hasil evaluasi RPP oleh ahli berada pada interpretasi sangat valid, dan hasil evaluasi LKPD oleh ahli dengan rata-rata interpretasi sangat valid. Perangkat pembelajran juga dinyatakan praktis berdasarkan hasil analisis angket praktikalitas peserta didik dan guru. Perangkat pembelajaran juga sudah dinyatakan praktis. Selain valid, dan praktis perangkat juga sudah dinyatakan efektif untuk meningkatkan kemampuan berpikir kritis peserta didik. Secara klasikal ketuntasan siswa meningkat dari semula $33 \%$ atau 11 orang menjadi 19 orang siswa atau $63 \%$. Hal ini berarti bahwa perangkat yang digunakan efektif untuk meningkatkan kemampuan berpikir kritis siswa SMP.

Kata kunci: Perangkat Pembelajaran, Model Eliciting Activities (MEAs), Kemampuan Berpikir Kritis

Copyright (c) 2021 Alhakko Latif, Damris, Kamid

$\triangle$ Corresponding author: Alhakko Latif

Email Address: alhakkolatif@gmail.com (Jl. Raden Mattaher No.16 Jambi, Kota Jambi, Indonesia)

Received 30 July 2021, Accepted 24 October 2021, Published 25 October 2021

\section{PENDAHULUAN}

Salah satu keterampilan abad 21 yaitu berpikir kritis masih menjadi keterampilan yang paling diperlukan untuk menjalani sebuah profesi dimasa kini dan di masa akan datang. The World Economic Forum tahun 2016 melansir 65\% anak-anak sekolah dasar pada akhirnya akan bekerja dalam jenis pekerjaan yang sama sekali belum ada sebelumnya dan menghadapi hal ini perlu keterampilan berpikir kritis. Karena itu, kemampuan berpikir kritis idealnya sudah mulai dikembangkan sejak awal. Tuntutan 
dunia yang semakin kompleks. Menurut mengharuskan siswa untuk memiliki kemampuan salah satunya berpikir kritis. Maka, keterampilan berpikir kritis harus diterapkan dan dikembangkan dalam kurikulum inti dan proses belajar mengajar untuk menghasilkan siswa yang nantinya akan menjadi pemimpin dengan cara berpikir berkualitas di masa depan (Firdaus, F., Kailani, I., Bakar, M. N. B., \& Bakry 2015).

Rendahnya kemampuan berpikir kritis siswa SMP dan belum tersedianya perangkat pembelajaran yang mendukung proses belajar yang melatih siswa untuk berpikir kritis dan membantu siswa memecahkan masalah non rutin menjadi sebab mengapa penelitian pengembangan perangkat pembelajaran berbasis MEAs ini diperlukan. Solusi yang ditawarkan berupa penelitian pengembangan perangkat pembelajaran berbasis MEAs diharapkan mampu mengatasi masalah kesulitan siswa membuat model matematika dari soal-soal yang berbentuk cerita dan rendahnya kemampuan berpikir kritis siswa SMP. MenurutFatmawati, H., Mardiyana, M., \& Triyanto (2014) juga menyarankan agar guru memfasilitasi siswa SMP dalam mengembangkan kemampuan berpikir kritis melalui desain pembelajaran instruksional, guru juga perlu mengarahkan siswa untuk memahami masalah terlebih dahulu kemudian mengubah soal cerita ke dalam model matematika sehingga siswa mampu mencari solusi lain dari suatu masalah.

RPP dan LKPD yang dikembangkan dalam penelitian ini didesain dengan pendekatan membuat dan menciptakan model matematika (mathematical modeling) yang siswa temukan sendiri. Pendekatan pembelajaran yang didesain melalui kegiatan menciptakan model matematikayang memberi kemungkinan siswa untuk mengingat kembali konsep-konsep, prosedur ataupun hukum matematika yang telah dipelajari sebelumnya, siswa pada mulanya membuat model matematika yang cukup sederhana kemudian lambat laun siswa dapat menguji, memformalkan, dan membuat generalisasi yang tepat (Turmudi, T., Hidayat, A. S., Prabawanto, S., \& Jupri 2014). Pendekatan pembelajaran melalui proses pemodelan matematika di kenal dengan pendekatan Model Eliciting Activities disingkat dengan MEAs (Lesh, R. E., \& Doerr 2003). Model Eliciting Activities (MEAs) merupakan sebuah pendekatan pembelajaran kooperatif yang bertujuan membantu siswa memecahkan masalah kehidupan nyata melalui proses pemodelan. Pentingnya kemampuan menciptakan model juga tersirat dari pendapat Sumarmo, U., Hidayat, W., Zukarnaen, R., Hamidah, M., \& Sariningsih (2012), bahwa matematika bersifat menekankan pada proses deduktif yang memerlukan penalaran logis dan aksiomatik, yang mungkin diawali dengan proses induktif yang meliputi penyusunan konjektur, model matematika, analogi dan atau generalisasi berdasarkan pengamatan terhadap sejumlah data.

Perangkat pembelajaran berbasis pendekatan Model Eliciting Activities (MEAs) cocok digunakan untuk meningkatkan kemampuan berpikir kritis siswa. Selain sebagai pendekatan yang berpusat pada siswa, tahapan maupun langkah-langkah dalam pembelajaran dengan pendekatan MEAs dapat melatih siswa dalam berpikir kritis. Contoh, pada langkah pertama Description, siswa dituntut mampu mengidentifikasikan informasi-informasi yang tersaji dalam masalah, dan siswa juga harus jeli melihat mana informasi yang terpakai dan mana yang tidak. Kegiatan ini adalah salah satu proses kegiatan berpikir kritis. 
Pendapat diatas didukung dengan hasil penelitian(Frank, B., Kaupp, J., \& Chen 2013); (Chan 2008); (Handajani, S., \& Pratiwi 2018); \&(Chamberlin, S. A., \& Moon 2005)yang menyimpulkan bahwa salah satu proses pendekatan pembelajaran yang berpusat pada siswa, berpotensi mengembangkan kemampuan berpikir kritis dan kreatif, dan terintegrasi dengan pembelajaran abad 21 adalah dengan menggunakaan pendekatan Model Eliciting Activities (MEAs). Menurut Baker, Galanti, and Birkhead (2017) juga menyebutkan, mengintegrasikan pembelajaran STEM (Science, Engineering, Technology and Mathematics) dikelas matematika dapat digunakan melalui pendekatan MEAs. Mendesain pembelajaran yang ditujukan untuk meningkatkan kemampuan berpikir kritis secara tidak langsung juga membantu melatih guru terbiasa dalam berpikir kritis.Menurut (Nio, Sukestiyarno, and Waluya (2017) menunjukkan kemampuan berpikir kritis guru masih rendah pada indikator menyimpulkan.

Sebelumnya telah ada penelitian pengembangan perangkat pembelajaran berbasis pendekatan MEAs yang hasilnya adalah LKPD yang valid, praktis dan efektif diantaranya penelitian (Meisya, S., Suhandri, S., \& Nufus 2018); (Rostari, Irwan, and Yulkifli 2018); (Wafiqoh, R., Darmawijoyo, D., \& Hartono 2016); (Wardawati, P. D., Irwan, I., \& Efendi 2018) namun belum ada penelitian pengembangan perangkat pembelajaran berbasis pendekatan MEAs yang ditujukan untuk meningkatkan kemampuan berpikir kritis dengan karakteristik siswa SMP, dan belum ditujukan untuk meningkatkan kemampuan berpikir kritis siswa khususnya aspek-aspek yang diujikan peneliti disekolah. Adanya penelitian pengembangan produk berupa RPP dan LKPD berbasis pendekatan berbasis MEAs yang valid, praktis, dan efektif diharapkan dapat memfalisitasi siswa dalam mengembangkan kemampuan berpikir kritis. Berdasarkan latar belakang tersebut, maka peneliti tertarik melakukan penelitian pengembangan tentang "Pengembangan Perangkat Pembelajaran Matematika berbasis Model Eliciting Activities (MEAs) untuk Meningkatkan Kemampuan Berpikir Kritis Siswa SMP”.

\section{METODE}

Jenis penelitian ini merupakan penelitian pengembangan (Design Research). Model pengembangan yang digunakan yaitu model Plomp. Peneliti memilih model pengembangan Plomp karena pada model pengembangan Plomp, produk yang didesain melewati beberapa kali penilaian sehingga kevalidan sebuah produk lebih terjamin, selain itu peneliti juga lebih memahami model pengembangan Plomp daripada model pengembangan lainnya. Prosedur penelitian dalam penelitian ini mengikuti prosedur model pengembangan Plomp yaitu preliminary research (penelitian pendahuluan), development or prototyping phase (tahap pengembangan atau pembuatan prototipe) dan assessmentphase (tahap penilaian). Secara umum, prosedur penelitian dapat dilihat pada tabel 1.

Tabel 1. Prosedur Penelitian

\begin{tabular}{|l|l|l|}
\hline \multicolumn{1}{|c|}{ Fase } & \multicolumn{1}{|c|}{ Fokus } & \multicolumn{1}{c|}{ Kegiatan } \\
\hline $\begin{array}{l}\text { Preliminary } \\
\text { Research }\end{array}$ & Analisis kebutuhan dan & konteks, \\
& Tinjauan literatur & $\begin{array}{l}\text { Analisis kebutuhan dan konteks, Tinjauan } \\
\text { literatur, yang hasilnya menjadi pedoman untuk } \\
\text { kerangka kerja dan cetak biru pertama/prototype } \\
1 \text { dari produk yang dikembangkan. }\end{array}$ \\
\hline
\end{tabular}


Pengembangan Perangkat Pembelajaran Matematika Berbasis Model Eliciting Activities (MEAs) untuk Meningkatkan Kemampuan Berpikir Kritis Peserta Didik SMP, Alhakko Latif, Damris, Kamid

\begin{tabular}{|l|l|l|}
\hline $\begin{array}{l}\text { Prototyping } \\
\text { Stage }\end{array}$ & $\begin{array}{l}\text { Fokus pada konsistensi } \\
\text { (validitas konstruk) dan } \\
\text { praktikalitas. Selanjutnya } \\
\text { mengutamakan praktikalitas } \\
\text { dan secara bertahap menuju } \\
\text { efektifitas. }\end{array}$ & $\begin{array}{l}\text { Pengembangan prototipe secara bertahap yang } \\
\text { akan diujicoba dan direvisi berdasarkan tahap } \\
\text { evaluasi formatif. Evaluasi formatif berlangsung } \\
\text { melalui penilaian ahliyang menghasilkan } \\
\text { kepraktisan yang diharapkan. }\end{array}$ \\
\hline $\begin{array}{l}\text { Assessment } \\
\text { Stage }\end{array}$ & $\begin{array}{l}\text { Praktikalitas dan efektivitas } \\
\text { Menilai apakah pengguna dapat menggunakan } \\
\text { produk dengan praktis (praktikalitas) dan efektif } \\
\text { serta berkeinginan untuk mengaplikasikannya. }\end{array}$ \\
\hline
\end{tabular}

Sumber: Diterjemahkan dan dimodifikasi dari Plomp, T. dan Nieveen (2013)

Secara ringkas, prosedur penelitian ini ditunjukkan pada gambar 1.

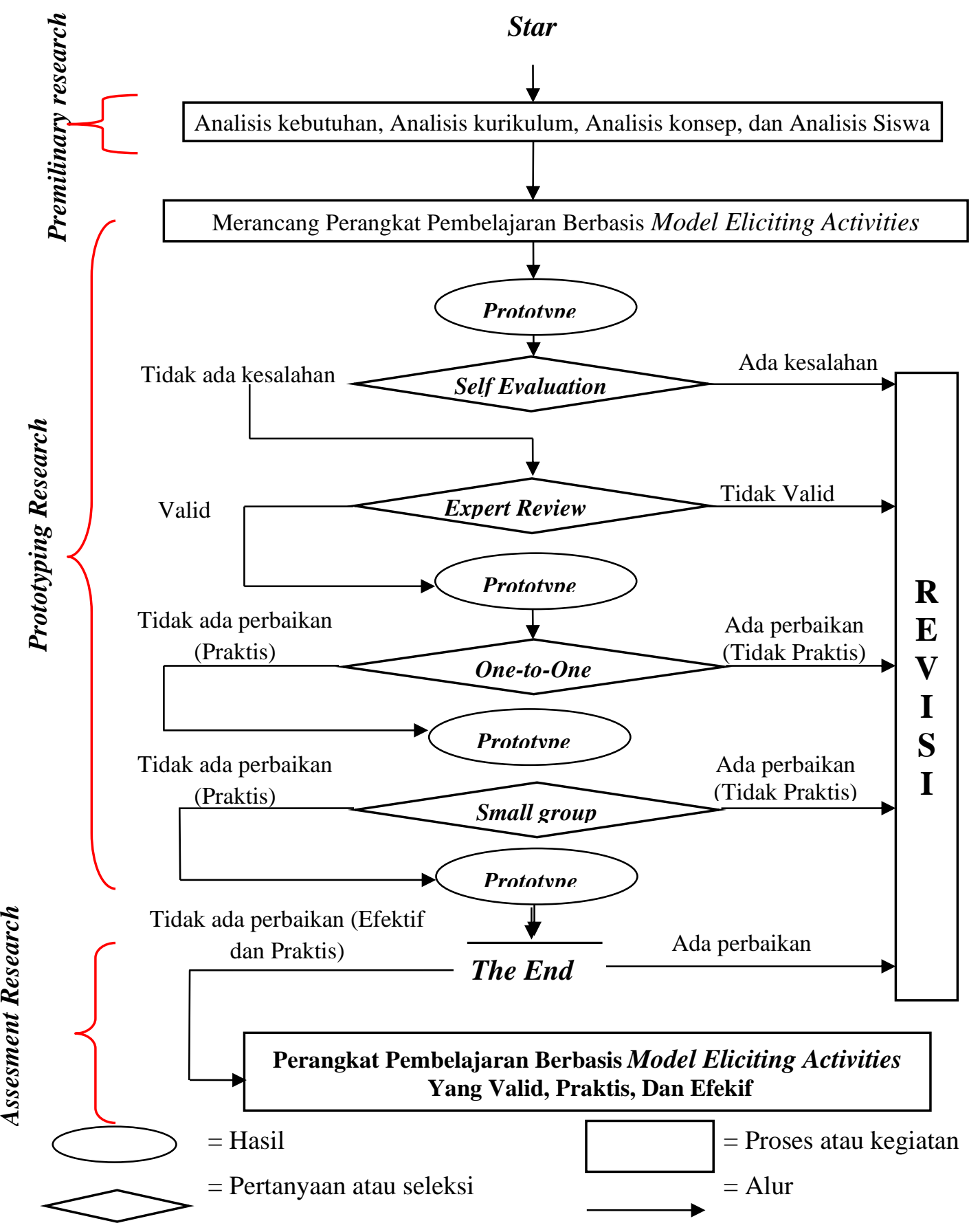

Gambar 1. Prosedur Penelitian 
Teknik analisis data penelitian ini terdiri dari tiga analisis yaitu analisis data validitas perangkat pembelajaran, analisis data praktikalitas perangkat pembelajaran, dan analisis data efektivitas. Analisis kevalidan dilakukan dengan menggunakan skala Likert dengan: setuju, tidak setuju. Data validitas dianalisis menggunakan rumus Fatmawati dalam(Sadam, A., Parida, S., Padol, A. R., Verma, A. D., Baba, N. A., Khuman, W. M., ... \& Sarkar 2017)sebagai berikut:

$$
\mathrm{V}=\frac{\text { total skor semua validator }}{\text { total skor maximal }} \times 100 \%
$$

keterangan:

$\mathrm{V}=$ nilai validitas instrumen ataupun perangkat

Tabel 2. Kriteria Validitas Perangkat Pembelajaran

\begin{tabular}{|c|c|}
\hline Kriteria (\%) & Interpretasi \\
\hline $75,01-100$ & Sangat valid \\
\hline $70,01-75,01$ & Valid \\
\hline $50,01-70$ & Rendah \\
\hline$\leq 0,50$ & Tidak valid \\
\hline
\end{tabular}

Sumber: Dimodifikasi dari Fatmawati dalam Sadam (2017)

Data yang berasal dari lembar praktikalitas dianalisis menggunakan analisis kuantitatif. Analisis dilakukan dengan menggunakan skala Likert dengan: setuju, tidak setuju. Nilai praktikalitas produk dengan rumus:

$$
P=\frac{R}{S M} \times 100 \%
$$

keterangan:

$P \quad=$ nilai praktikalitas

$R=$ jumlah rerata skor semua item, dihitung dengan cara menghitung jumlah nilai yang diberi oleh responden dibagi banyak responden.

$S M=$ jumlah skor maksimal semua item

Kategori praktikalitas keterlaksanaan pembelajaran dengan penggunaan perangkat pembelajara dengan pendekatan Model Eliciting Activities (MEAs) ditentukan dengan kriteria pada tabel 16.

Tabel 3. Kategori Praktikalitas Perangkat Pembelajaran

\begin{tabular}{|c|c|}
\hline Tingkat Pencapaian (\%) & Kategori \\
\hline$\leq 25$ & Tidak praktis \\
\hline $26-40$ & Kurang praktis \\
\hline $41-60$ & Cukup praktis \\
\hline $61-170$ & Praktis \\
\hline$\geq 171$ & Sangat praktis \\
\hline
\end{tabular}

Sumber: Dimodifikasi dari (Riduwan 2005) 
Tujuan analisis data efektivitas adalah untuk menyelidiki apakah tujuan pembelajaran dapat dicapai oleh siswa. Analisis dilakukan dengan melihat carasiswa dalam menyelesaikan soal berpikir kritis dan strategi yang digunakan sesuai dengan indikator yang telah ditetapkan. Hasil pre-test tidak dianalisis secara kuantitatif karena nilai pre-test tidak dibandingkan dengan nilai post-test. Analisis data hasil pre-test peserta didik bertujuan untuk memberikan informasi tentang pengetahuan awal siswa. Perkembangan kemampuan berpikir kritis siswa pada setiap indikator dilihat dari hasil pre-test, hasil kerja pada saat mengikuti pembelajaran, dan hasil post-test. Dari hasil analisis tersebut terlihatkemajuan yang ditunjukkan siswa dari awal hingga akhir pembelajaran. Hasil post-test dinilai sesuai dengan rubrik penilaian yang telah disusun. Selanjutnya, untuk melihat efektivitas alur belajar dilakukan analisis terhadap hasil post-test yang terkait dengan kemampuan berpikir kritis siswa. Analisis dilakukan dengan teknik penilaian yang dinyatakan oleh Purwanto (2009) berikut ini.

$$
S=\frac{R}{N} \times 100
$$

Keterangan:

$\mathrm{S}=$ Nilai siswa

$R=$ Jumlah skor yang diperolah siswa

$N=$ Skor maksimum

Tabel 4. Kriteria Ketuntasan Setiap Siswa

\begin{tabular}{|c|c|c|}
\hline Tingkat Penguasaan & Predikat & Keterangan \\
\hline $176-100$ & Sangat baik & Tuntas \\
\hline $76-175$ & Baik & tuntas \\
\hline $60-75$ & Cukup & tuntas \\
\hline $55-59$ & Kurang & Tidak tuntas \\
\hline$\leq 54$ & Kurang sekali & Tidak tuntas \\
\hline
\end{tabular}

Sumber: Dimodifikasi dari (Purwanto 2009)

Persentase yang diperoleh, dikonfirmasikan pada kriteria yang ditetapkan.

Persentase ketuntasan klasikal dihitung dengan menggunakan rumus dalam Trianto (2009)sebagai berikut:

$$
\text { ketuntasan } \text { klasikal }=\frac{\text { jumlah } \text { siswa yang tuntas }}{\text { jumlah seluruh siswa }} \times 100 \%
$$

Berdasarkan pertimbangan hasil tes awal kemampuan berpikir kritis siswa maka perangkat pembelajaran yang dikembangkan dikategorikan efektif jika ketuntasan klasikal $\geq 50 \%$ (dimodifikasi dari (Purwanto 2009).

\section{HASIL DAN DISKUSI}

\section{Hasil Penelitian Pendahuluan (Preliminary Research)}

Kegiatan yang dilakukan selama tahap investigasi awal mencakup analisis praktek pengguna (analisis kebutuhan dan konteks) dan eksplorasi dasar pengetahuan ilmiah (kajian literatur). Berdasarkan 
hasil analisis kebutuhan diperoleh informasi bahwa dalam proses pembelajaran di kelas guru belum menggunakan perangkat pembelajaran yang dapat mendukung tercapainya tujuan pembelajaran. Guru telah memiliki perangkat pembelajaran berupa RPP dan LKPD namun terkadang penggunaan perangkat yang disiapkan tidak sesuai dalam pelaksanaannya. Ditengah proses pembelajaran, guru kadang harus kembali mengajar secara konvensional karena waktu pembelajaran tidak mencukupi. Terkait penggunaan LKPD diperoleh informasi bahwa guru hanya menggunakan LKPD yang dibeli di percetakan sebagai, guru kekurangan ide dalam membuat LKPD.

Pada analisis kurikulum diperoleh informasi bahwa SMP Negeri 2 sarolangun telah menerapkan kurikulum 2013. Tahap ini berfokus pada analisis KI dan KD yang akan diuraikan dalam bentuk indikator-indikator kompetensi pembelajaran. Indikator kompetensi pembelajaran dikembangkan berdasarkan KD. Kata kerja yang digunakan untuk mengembangkan indikator menggunakan Taksonomi Anderson (Perbaikan Taksonomi Bloom). Berdasarkan taksonomi kata kerja operasional dari KD yang tersedia berada pada level kognitif C4 maka kata kerja operasional untuk indikator dibuat pada level C1 sampai C4. Berdasarkan analisis konsep diperoleh bahwa materi yang dipelajari selama semester ganjil adalah pola bilangan, koordinat kartesius, relasi dan fungsi, persamaan garis lurus dan persamaan linear dua variabel.

Pada analisis peserta didik, menurut teori perkembangan kognitif Piaget diketahui bahwa peserta didik SMP sudah memasuki masa remajadimana mereka sudah memiliki pola pikir sendiri dalam usaha memecahkan masalah-masalah yang kompleks dan abstrak. Peserta didik SMP sudah mampu membayangkan alternatif pemecahan masalah beserta kemungkinan akibat atau hasilnya. Hal ini berarti peserta didik SMP sudah memiliki kemampuan berpikir kritis, maka metode pembelajaran yang cocok untuk anak diusia ini bukan lagi pembelajaran satu arah melainkan pembelajaran yang dapat membantu mengembangkan pola pikir abstrak peserta didik. Sehingga, ketika mereka lulus dari sekolah menengah nanti mereka sudah terbiasa berpikir kritis dan mampu menganalisis masalah untuk kemudian mencari solusi yang terbaik. Hasil angket menunjukkan bahwa peserta didik masih kesulitan saat memecahkan masalah cerita, masalah tingkat tinggi dan masalah yang berkaitan dengan kehidupan nyata. Peserta didik SMP juga lebih suka pembelajaran berkelompok. Terkait dengan LKPD, peserta didik menginginkan LKPD yang berwarna, berpenampilan menarik disertai gambar-gambar dan stiker serta menggunakan tulisan Comic San MS. Hasil analisis karakteristik siswa ini nantinya akan menjadi pertimbangan peneliti dalam mengembangkan produk.

\section{Hasil Tahap Pengembangan (Development or Prototyphing Phase)}

Prototype awal didesain berdasarkan hasil dari studi pendahuluan. Produk yang didesaian adalah perangkat pembelajaran berupa RPP dan LKPD. RPP dan LKPD didesain dengan memperhatikan langkah dan prinsip pendekatan MEAs. Komponen-komponen dalam RPP disusun didasarkan pada Permendikbud Nomor 22 tahun 2016 sementara penyusunan komponen dalam LKPD mengacu pada pendapat yang dikemukakan oleh Prastowo (2011). Berikut akan dipaparkan protitipe pertama yang dirancang oleh peneliti. 


\section{Desain RPP}

RPP didesain untuk materi pokok pola bilangan. Hasil penelitian pendahuluan berupa analisis KD pada silabus dan diskusi dengan guru matematika maka materi yang dipelajari terdiri daristatistika, bangun ruang sisi datar, trigonometri, lingkaran, statistika, peluang, pola bilangan, bidang kartesius, relasi dan fungsi, dan persamaan garis lurus. Mengingat keterbatasan waktu maka materi yang akan diujicobakan adalah materi pola bilangan dengan sub materi pola bilangan pada barisan bilangan, pola konfigurasi objek, ragam pola bilangan, barisan aritmetika, deret aritmetika, barisan geometri dan deret geometri. RPP dirancang sebanyak 6 kali pertemuan. Indikator capaian kompetensi mengacu pada KD dan menggunakan kata-kata kerja operasional yang sesuai. Taksonomikata kerja operasional dari KD yang tersedia disilabus berada pada level kognitif C4 maka kata kerja operasional untuk indikator dibuat pada level C1 sampai C4. Langkah-langkah pembelajaran dalam RPP disesuaikan dengan langkahlangkah MEAs. Berikut akan dipaparkan langkah-langkah pembelajaran pada desaian awal.

Kegiatan yang dirancang pada langkah pendahuluan ini terdiri dari kegiatan orientasi, memberikan apersepsi dan memberi motivasi. Waktu yang disediakan untuk kegiatan pendahuluan adalah 10 menit. Pada step ini guru membagi peserta didik kedalam beberapa kelompok yang masingmasing kelompok terdiri dari 4 orang peserta didik. Setelah guru mempersiapkan peserta didik dan menjelaskan metode pembelajaran dan tekhnik penilaian, peserta didik duduk pada kelompoknya masing-masing. Guru juga mengecek dan mengingatkan kembali materi-materi prasyarat seperti menebak bilangan berikutnya dari barisan bilangan atau gambar yang berpola. Materi ini sudah dipelajari peserta didik di sekolah dasar. Kemudian guru memberi motivasi pada peserta didik berupa manfaat-manfaat yang akan mereka dapatkan dalam mempelajari pola bilangan.

Kegiatan inti disesuaikan dengan prinsip dan langkah-langkah pendekatan MEAs. Waktu yang disediakan untuk kegiatan inti sebanyak 60 menit. Kegiatan pertama yang dilakukan pada kegiatan inti adalah peserta didik membaca, mengamati dan menanya tentang masalah nyata yang diberikan. Memberikan masalah nyata merupakan prinsip dari pendekatan MEAs yaitu The Reality Principle. Setelah peserta didik diyakinimemahami masalah-masalah yang diberikan pada LKPD, kegiatan dilanjutkan dengan description dan manipulation (memodelkan dan menentukan solusi). Pada kegiatan ini peserta didik diminta membuat model dan menentukan solusi dari masalah yang diberikan. Prinsip yangdipakai pada step ini adalah "The model Documentation Principle dan The Model Construction Principle". Prinsip ini menuntut peserta didik mampu membuat dan mengembangkan model matematika untuk menyelesaikan masalah dengan sukses. Berawal dari mengidentifikasi informasi yang diperoleh ke dalam bentuk matematika melatih peserta didik untuk menganalisis situasi kehidupan nyata, fokus pada tujuan, hubungan, tindakan dan pola, mengidentifikasi kekuatan dan kelemahan dari cara berpikir alternatif dan menghilangkan model yang tidak pantas dan kurang fungsional. Prinsip ini juga meminta peserta didik untuk bekerja pada tempat-tempat yang telah disediakan, hal ini melatih peserta didik untuk bekerja secara teratur dan sistematis. Kemudian kegiatan terakhir pada kegiatan inti dilanjutkan dengan Predictiondan verification. Pada step ini peserta didik diharuskan untuk mengecek 
kembali solusi yang dibuat agar tidak terjadi kesalahan. Hal ini juga sesuai dengan prinsip MEAs yaitu the self-assessment. Sementara kegiatan mempresentasikan kerja kelompok menggunakan prinsip construct share ability and re-usability dan prinsip effective prototype. Kegiatan terakhir dari kegiatan ini menuntut peserta didik membuat generalisasi dan memeriksa hasil yang diberikan agar dapat disesuaikan dengan situasi lain dan dapat digunakan oleh orang lain.

Desain LPD

Prototype pertama LKPD didesain dengan memperhatikan prinsip dan langkah-langkah MEAs dan mempertimbangkan analisis peserta didik pada hasil penelitian pendahuluan yang telah diperoleh. LKPD didesain berwarna, berpenampilan menarik disertai gambar-gambar dan stiker serta menggunakan tulisan Comic San MS. Komponen-komponen yang disusun pada LKPD yaitu petunjuk belajar, kompetensi yang akan dicapai, informasi pendukung, latihan-latihan, petunjuk kerja, dan evaluasi.

Hasil Evaluasi Perangkat oleh Ahli (Expert Review)

Evaluasi dilakukan oleh lima orang pakar yaitu tiga orang pakar matematika, satu orang pakar teknologi dan satu orang pakar bahasa indonesia. Hasil evaluasi prototype 1 pada perangkat dan tabel 5 serta tabel 6.

Tabel 5. Hasil Evaluasi RPP oleh Ahli

\begin{tabular}{|l|l|c|l|}
\hline No & \multicolumn{1}{|c|}{ Komponen Penilaian } & $\begin{array}{c}\text { Nilai Validitas } \\
(\mathbf{V})\end{array}$ & \multicolumn{1}{|c|}{ Inpretasi } \\
\hline 1 & Komponen RPP & 89,58 & Sangat valid \\
\hline 2 & $\begin{array}{l}\text { Kesesuaian kegiatan pembelajaran dengan } \\
\text { prinsip dan langkah kegiatan pendekatan MEAs }\end{array}$ & 91,67 & Sangat valid \\
\hline 3 & Manfaat & 87,50 & Sangat valid \\
\hline 4 & Bahasa & 87,50 & Sangat valid \\
\hline
\end{tabular}

Tabel 6. Hasil Evaluasi LKPD oleh Ahli

\begin{tabular}{|l|l|l|l|}
\hline No & Komponen Penilaian & Nilai Validitas (V) & \multicolumn{1}{c|}{ Inpretasi } \\
\hline 1 & Penyajian & 91,67 & Sangat valid \\
\hline 2 & Kelayakan isi & 94,38 & Sangat valid \\
\hline 3 & Bahasa & 87,50 & Sangat valid \\
\hline 4 & Tampilan & 75,00 & Valid \\
\hline
\end{tabular}

Setelah revisi yang disarankan selesai dilakukan dan memperoleh hasil valid atau sangat valid dari ahli, maka selanjutnya perangkat akan masuk pada tahap evaluasi perorangan atau one to one evalution.

\section{Hasil Evaluasi Perorangan}

Kegiatan Evaluasi one to one dilakukan sebanyak 6 kali pertemuan dengan materi pola bilangan. Kegiatan one to one evaluation dilakukan pada 3 orang peserta didik yang berkemampuan tinggi, sedang, dan rendah. peserta didik dipilih berdasarkan atas pertimbangan guru. peserta didik yang dipilih berasal dari kelas VIII B dan tidak ikut serta dalam evaluasi small group dan field tes. Dalam One-to- 
one Evaluation dilakukan kegiatan mengidentifikasi kejelasan produk, kejelasan arah, kelengkapan perangkat, tingkat kesulitan, kesalahan dan tata bahasa. Perangkat yang digunakan pada tahap one to one evalutioan adalah perangkat yang telah melalui evaluasi ahli atau expert review atau dikenal dengan prototype 3. Pada tiap pertemuan LKPD diberikan pada 3 orang peserta didik yang dijadikan sampel. Secara bergantian peneliti mengobservasi kegiatan peserta didik. sebelum memulai, terlebih dahulu peneliti menjelaskan pada peserta didik tentang kegiatan yang harus dilakukan. Peneliti menggunakan instrumen lembar observasi dan lembar wawancara.

Berdasarkan hasil wawancara diperoleh informasi bahwa peserta didik secara umum menyukai LKPD yang diberikan karena berwarna, pada awalnya siswaa merasa kesulitan dalam menyelesaikan LKPD namun lama kelamaan peserta didik sudah bisa mengikuti setiap langkah-langkah penyelesaian dalam LKPD. Waktu yang diberikan pada peserta didik terkadang cukup untuk peserta didik menyelesaikan LKPD namun terkadang ada LKPD yang membutuhkan waktu yang lebih banyak untuk menyelesaikannya. LKPD yang diberikan dapat dibaca dengan jelas. Langkah-langkah penyelesaian pada LKPD membantu peserta didik menyelesaikan masalah non rutin yang diberikan dan membantu melatih peserta didik berpikir kritis. Hasil revisi dari one to one evalution ini dikenal dengan prototype 3 dan selanjutnya prototype 3 akan dievaluasi kembali pada kelompok kecil atau dikenal dengan small group evalution.

\section{Hasil Evaluasi Kelompok Kecil (Small Group Evaluation)}

Sama seperti halnya kegiatan evaluasi one to one, evaluasi small group juga dilakukan sebanyak 7 kali pertemuan dengan materi pola bilangan. Kegiatan small group evalutiondilakukan pada 6 orang peserta didik antara lain 2 orang berkemampuan tinggi, 2 orang berkemampuan sedang dan 2 orang berkemampuan rendah. peserta didik dipilih berdasarkan atas pertimbangan guru. Peserta didik yang dipilih berasal dari kelas VIII 1 dan tidak ikut serta dalam evaluasi one to one dan field tes.

Kegiatan small group juga melibatkan guru yang akan mengajar dikelas field test, hal ini dilakukan agar guru yang bersangkutan dapat melihat bagaimana proses pembelajaran akan dilaksanakan di kelas field tes nantinya. Instrumen yang digunakan peneliti pada evaluasi small group berupa lembar observasi dan angket praktikalitas. Proses pembelajaran dilakukan dengan menerapkan pendekatan pembelajaran berbasis MEAs dan didukung dengan LKPD berbasis MEAs. Tiap pertemuan siswa dilatih untuk berpikir kritis sesuai dengan indikator kemampuan berpikir kritis yang telah dibuat peneliti. Kegiatan-kegiatan yang akan dievaluasi pada tahap ini adalah kemudahan dalam penggunaan, waktu yang diperlukan dalam pelaksanaan, daya tarik produk terhadap peserta didik, dan mudah diinterpretasikan atau dipahami. Tabel 5 memperlihatkan kepraktisan LKPD pada tahap small group evalution. Aspek kemudahan penggunaan, efisiensi waktu, daya tarik, kemudahan untuk dipahami dan manfaat memiliki kriteria praktis. Tidak jauh berbeda dengan respon peserta didik pada saat one to one evalution, respon peserta didik pada awalnya menganggap bahwa LKPD dan masalah-masalah yang dicontohkan sulit untuk dikerjakan namun setelah 2 hingga 3 kali pertemuan peserta didik sudah dapat menggunakan LKPD dan merasakan manfaatnya. 
Perihal yang harus dipertegas tiap pertemuan pada small group evaluation adalah setiap pertemuan guru harus menjelaskan kepada peserta didik tentang tujuan pembelajaran terkait indikator kemampuan berpikir kritis yang akan dilatih dan indikator tersebut muncul pada pertanyaan tiap masalah yang diberikan. Hal ini dilakukan agar saat pembelajaran berlangsung peserta didik tidak lagi bertanya. Kepraktisan LKPD pada tahap small group evalution memiliki nilai 96,61.

\section{Hasil Asessment Phase}

Tahap penilaian dilakukan melalui field tes, perangkat yang digunakan adalah prototype 4 yang merupakan hasil dari evaluasi small group. Pada tahap ini akan diukur kepraktisan dan keefektifan produk yang dikembangkan. Instrumen yang digunakan oleh peneliti pada tahap penilaian berupa lembar observasi, angket praktikalitas dan tes akhir peserta didik. Pengukuran kepraktisan akan dilihat dari hasil angket praktikalitas yang akan diisi peserta didik dan guru, keefektifan akan dilihat dari hasil tes akhir peserta didik sementara lembar observasi digunakan untuk melihat keterlaksanaan pendekatan pembelajaran berbasis MEAs dikelas. Subjek penelitian tahap field test adalah peserta didik kelas VIII 1 berjumlah 30 orang dan yang bertindak sebagai guru adalah guru matematika yang mengajar dikelas VIII 1. Hasil observasi menunjukkan bahwa guru sudah dapat melaksanakan pembelajaran sesuai dengan RPP berbasis pendekatan pembelajaran MEAs yang telah dibuat peneliti.

Berdasarkan hasil angket praktikalitas peserta didik diperoleh nilai 80,41 dengan kriteria praktis. Hal ini menunjukkan bahwa LKPD dapat digunakan peserta didik. Hasil angket dapat dilihat praktikalitas peserta didik dapat dilihat pada tabel berikut.

Tabel 7. Hasil Angket Praktikalitas Peserta Didik

\begin{tabular}{|l|l|c|c|}
\hline No & \multicolumn{1}{|c|}{ Aspek } & P & Kriteria ke praktisan \\
\hline 1 & Kemudahan penggunaan & 81,85 & Sangat praktis \\
\hline 2 & Efisiensi waktu & 75,89 & praktis \\
\hline 3 & Daya tarik & 80,80 & praktis \\
\hline 4 & Kemudahan untuk dipahami & 79,46 & praktis \\
\hline 5 & Manfaat LKPD & 80,71 & Praktis \\
\hline & Rata-rata & 80,21 & praktis \\
\hline
\end{tabular}

Data hasil tes akhir siswa dianalisis dengan menggunakan teknik persentase. Persentase kenaikan jumlah siswa yang mendapatkan skor maximal tiap indikator dapat dilihat pada tabel 30.

Tabel 8. Persentase kenaikan jumlah peserta didik yang mendapatkan skor maximal tiap indikator.

\begin{tabular}{|c|l|c|c|}
\hline \multirow{2}{*}{ No } & \multicolumn{1}{|c|}{ Indikator } & \multicolumn{2}{c|}{$\begin{array}{c}\text { Persentase siswa dengan jawaban } \\
\text { maximum (\%) }\end{array}$} \\
\cline { 3 - 4 } & \multicolumn{1}{|c|}{ Hasil pretes } & Hasil postest \\
\hline 1 & $\begin{array}{l}\text { Mengidentifikasi informasi-informasi atau } \\
\text { data-data yang mendukung }\end{array}$ & 13 & 13 \\
\hline 2 & Memeriksa kebenaran konsep & 7 & 10 \\
\hline
\end{tabular}


Pengembangan Perangkat Pembelajaran Matematika Berbasis Model Eliciting Activities (MEAs) untuk Meningkatkan Kemampuan Berpikir Kritis Peserta Didik SMP, Alhakko Latif, Damris, Kamid

\begin{tabular}{|c|l|c|c|}
\hline 3 & Memeriksa asumsi atau argumen & 50 & 47 \\
\hline 4 & Memberikan alternatif dugaan penyelesaian & 13 & 50 \\
\hline 5 & $\begin{array}{l}\text { Menggeneralisasikan atau membuat } \\
\text { kesimpulan dari model matematika yang } \\
\text { telah dibuat }\end{array}$ & 23 & 50 \\
\hline
\end{tabular}

Pada tabel 8 terlihat bahwa terjadi peningkatan jumlah persentase peserta didik yang mendapatkan skor maximal pada beberapa indikator antara lain indikator memeriksa kebenaran konsep, memberikan alternatif dugaan penyelesaian dan indikator menggeneralisasikan atau membuat kesimpulan dari model matematika yang telah dibuat. Sementara indikator mengidentifikasi informasiinformasi atau data-data yang mendukung tidak mengalami peningkatan dan indikator memeriksa asumsi atau argument mengalami penurunan. Jika dilihat dari jawaban siswa, tidak meningkatnya kemampuan berpikir kritis siswa pada indikator memeriksa asumsi atau argument disebabkan oleh kesalahan dalam perhitungan. Jadi, konsep dasar aljabar siswa masih perlu dilatihkan lebih banyak sementara pada indikator mengidentifikasi informasi-informasi atau data-data yang mendukung tidak mengalami peningkatan karena jawabansiswa masih belum lengkap. Sehingga siswa masih perlu dilatihkan dalam hal ketelitian. Secara klasikal ketuntasan siswa meningkat dari semula $33 \%$ atau 11 orang menjadi 19 orang siswa atau $63 \%$. Hal ini berarti bahwa perangkat yang digunakan efektif untuk meningkatkan kemampuan berpikir kritis siswa SMP

\section{Diskusi}

Perangkat pembelajaran berbasis MEAs berupa RPP dan LKPD telah melalui serangkaian uji validitas, kepraktisan dan juga telah diuji efektivitasnya. Terdapat beberapa revisi terhadap rancangan awal produk dengan hasil akhir produk. Setelah melalui validasi ahli dan uji coba produk baik itu one to one, small group maupun field test diperoleh kesimpulan bahwa perangkat pembelajaran berbasis MEAs valid, praktis dan efektif dalam meningkatkan kemampuan berpikir kritis peserta didik SMP.

Penelitian yang dilakukan oleh Rahma Wulandari tentang pengembangan lembar kerja peserta didik (LKPD) menggunakan model MEAs pada materi SPLTV menyatakan bahwa Model-Eliciting Activities (MEAs) merupakan salah satu pendekatan yang mampu meningkatkan kemampuan pemodelan siswa untuk memodelkan permasalahan ke bentuk model matematika. Pengembangan MEAs memiliki dua tujuan dalam pemikiran saat diciptakannya MEAs. MEAs akan mendorong siswa untuk membuat model matematis untuk memecahkan masalah yang kompleks, sama seperti yang diterapkan matematikawan di dunia nyata.

Penelitian tentang pembelajaran berbasis MEAs juga pernah diteliti oleh (Nurlaili, N., \& Muhartono 2017) yang menyatakan bahwa perangkat pembelajaran yang dihasilkan dapat meningkatkan kemampuan pemecahan masalah peserta didik. Hal ini dikarenakan pembelajaran dengan menggunakan pendekatan MEAs membiasakan peserta didik untuk menyelesaikan soal-soal pemecahan masalah yang memiliki kriteria realistik, open-ended dan/atau non-rutin. 
Penelitian lain yang pernah diteliti oleh Khalid, F. S., Irwan, J. M., Ibrahim, M. W., Othman, N., \& Shahidan (2018)yang meneliti tentang Pengembangan Pembelajaran Matematika Model MEAs Untuk Meningkatkan Penguasaan Konsep Matematika Siswa diperoleh hasil penelitian bahwa berdasarkan hasil tes hasil belajar siswa dapat ditarik kesimpulan bahwa pembelajaran yang dikembangkan memiliki kualitas efektif.

Hal senada juga penulis temui dalam penelitian ini yang mengungkapkan bahwa prinsip pembelajaran berbasis MEAs merupakan solusi untuk meningkatkan kemampuan pemecahan masalah dan kemampuan meningatkan penguasaan konsep berpikir kritis peserta didik SMP dibuktikan dengan hasil tes yang telah dianalisis oleh peneliti.

Adanya RPP dan LKPD sangat membantu pendekatan pembelajaran berbasis MEAs diterapkan pada siswa sehingga pembelajaran berjalan dengan baik dan efektif. Setiap pertemuan tujuan pembelajaran di rancang untuk melatih siswa berpikir kritis sesuai dengan indikator kemampuan berpikir kritis yang telah dirumuskan. Hasil temuan menunjukkan bahwa pada setiap pertemuan siswa baru pertama kali menemukan pertanyaan-pertanyaan berpikir kritis seperti yang ada dalam LKPD.

Hal senada pernah ditelti oleh Meisya, S., Suhandri, S., \& Nufus (2018) yang menyatakan bahwa LKPD matematika berbasis Model-Eliciting Activities (MEAs) yang telah dikembangkan peneliti memiliki pengaruh terhadap kemampuan komunikasi matematis siswa atau dengan kata lain, LKS berbasis Model-Eliciting Activities efektif untuk digunakan dalam memfasislitasi kemampuan komunikasi matematis siswa lebih khususnya pada materi kubus dan balok.. Hal tersebut juga sesuai dengan masalah yang peneliti berikan pada tiap LKPD yang merupakan masalah nyata. Memberikan masalah nyata pada siswa berarti memberikan kesempatan pada siswa untuk berlatih mengerjakan masalah non rutin. Masalah non rutin adalah hal yang menakutkan bagi siswa karena biasanya masalah non rutin disajikan dalam bentuk cerita dan menuntut siswa dalam mengingatkonsepkonsep pembelajaran yang telah mereka pelajari.

Menurut Richard, C., Jensen, I., \& Guttmann (2003) menyatakan bahwa MEAs disebut sebagai pendekatan pembelajaran yang didasari pada masalah nyata, bekerja dalam tim kecil, dan membuat sebuah model matematika untuk membantu siswa membangun solusi atas masalah yang diberikan dan mengharuskan siswa menerapkan konsep matematika yang telah dipelajari sebelumnya.

Memberikan masalah nyata pada tiap pertemuan pembelajaran agar siswa terbiasa mengerjakan masalah-masalah non rutin tersebut karena untuk membuat siswa terbiasa maka harus diberikan secara berulang atau dikenal dengan teori belajar Thorndike.

Sesuai dengan pengertiannya, pendekatan pembelajaran berbasis MEAs adalah pembelajaran berkelompok. Maka pada pertemuan pertama guru membagi siswa menjadi beberapa kelompok.

Langkah pertama dalam pembelajaran berbasis pendekatan MEAs yaitu description sangat membantu siswa untuk mengetahui permasalahan dengan jelas. Pada langkah ini siswa diharuskan untuk terlebih dahulu mengidentifikasi informasi-informasi dari masalah yang diberikan dan membuat model matematika yang tepat. Dari hasil identifikasi masalah yang telah dibuatLesh, R. E., \& Doerr (2003) 
yang mendefinisikan bahwa proses pemodelan sebagai serangkaian kegiatan yang bertujuan untuk mengembangkan keterampilan eksplorasi dan penemuan siswa, dan kegiatan ini termasuk mengubah masalah kehidupan nyata menjadi masalah matematika kemudian membuat keputusan mengenai bagaimana masalah diselesaikan, bagaimana ide direncanakan dan dikembangkan, apakah ide perlu direvisi atau pemikiran yang lebih komprehensif, dan apakah ide-ide termasuk kondisi dan asumsi yang disediakan dalam masalah(Wulandari R., Susanti, E., \& Santoso 2018).

Pada langkah ini juga prinsip konstruksi model atau The Model Construction Principle diterapkan. Hal ini berarti siswa dituntut untuk merancang masalah hingga terciptanya suatu model yang berhubungan dengan unsure-unsur, operasi antar unsur, atau pola dan aturan yang mengatur hubungan yang terdapat pada masalah yang diidentifikasikan.

Langkah kedua dalam pembelajaran berbasis pendekatan MEAs yaitu manipulation. Pada langkah ini Siswa mulai berpikir menghasilkan solusi atas masalah yang diberikan. Berdasarkan penelitian yang dilakukan oleh Wulandari R., Susanti, E., \& Santoso(2018) yang menyatakan bahwa pada langkah ini, siswa juga harus mampu memahami permasalahan dengan tepat untuk dapat menyelesaikan permasalahan yang ada . Prinsip The Model Documentation Principle atau prinsip dokumentasi model diterapkan pada langkah ini. Maka, pada langkah kedua siswa harus mampu mengungkapkan dan mendokumentasikan proses berpikir dalam solusi mereka. Yulianti, D. E., Wuryanto, W., \& Darmo (2013)menyatakan bahwa siswa harus mampu menyatakan pemikiran mereka sendiri selama bekerja dalam MEAs dan bahwa proses berpikir mereka harus didokumentasikan dalam solusi. Prinsip ini berhubungan dengan self-assessment. Berdasarkan pengamatan peneliti, menuangkan solusi atau menuliskan solusi akan melatih siswa untuk dapat menuangkan ide dalam bentuk tulisan, mengembangkan pola berpikir siswa menjadi lebih luas. Selanjutnya adalah prinsip effective prototype artinya memastikan bahwa model yang dihasilkan akan sesederhana mungkin namun tetap signifikan secara matematis. Hal ini senada dengan penelitianYulianti, D. E., Wuryanto, W., \& Darmo (2013) yang menyatakan bahwa model yang dihasilkan harus dapat mudah ditafsirkan dengan mudah oleh orang lain.

Langkah ketiga dalam pembelajaran berbasis pendekatan MEAs yaitu prediction. Pada langkah ini siswa membuat prediksi-prediksi dan mengubah hasil yang diperoleh kembali ke situasi kehidupan nyata sehingga siswa dapat menilai kegunaan solusi yang didapatkan dalam kehidupan sehari-hari. Penelitian yang dilakukan oleh Nurlaili, N., \& Muhartono (2017) menyatakan bahwa permasalahan yang realistis memungkinkan solusi kreatif dari siswa, oleh karena itu konteks situasi harus masuk akal dari segi pengalaman dan pengetahuan kehidupan nyata. Dalam langkah prediction berarti siswa mampu membuat kesimpulan yang tepat berdasarkan solusi yang diperoleh. Hal ini juga melatih siswa dalam berpikir kritis dalam hal membuat kesimpulan atau menggeneralisasikan dari model matematika yang dibuat.

Selanjutnya adalah The Construct Share ability and Reusability Principle atau prinsip kemampuan bersama dan digunakan kembali yang diterapkan dalam langkah ini, artinya solusi yang dibuat oleh siswa harus digeneralisasikan atau mudah disesuaikan dengan situasi lain dan dapat 
digunakan oleh orang lain. Hal ini senada dengan penelitian yang telah dilakukan oleh Zulkarnaen (2018) yang menyatakan bahwa prinsip ini harus mewakili secara umum berpikir bukan solusi spesifik untuk konteks tertentu. Prinsip ini juga memastikan bahwa siswa dapat mengkomunikasikan dengan cara yang dimengerti jelas yang memungkinkan model yang dihasilkan dapat digunakan oleh siswa. Selanjutnya langkah verification artinya siswa diminta untuk mengecek setiap langkah solusi yang diperolah agar tidak ada kesalahan solusi.

Pada penelitian ini, langkah pada tahap ini diterapkan dengan cara siswa bersama kelompoknya yang diberi kesempatan ataupun ditunjuk langsung oleh guru menyampaikan (mengkomunikasikan) solusi dari diskusi kelompoknya. Sementara kelompok lain memeriksa dan membandingkan jawaban mereka dengan jawaban kelompok yang maju ke depan. The Self-Assessment Principle atau prinsip Penilaian diri diterapkan dalam langkah ini. Maka, artinya siswa harus dapat menilai diri atau mengukur kegunaan dari solusi mereka.

Keunggulan Produk LKPD yang dihasilkan dalam penelitian ini dibandingkan penelitian oleh adalah adalah pada pertanyaan-pertanyaan dari masalah yang diberikan dimana pertanyaan-pertanyaan pada setiap masalah difokuskan untuk melatih kemampuan berpikir kritis siswa. selain itu, pada LKPD peneliti tidak menyajikan pendahuluan ataupun ringkasan materi melainkan langsung menyajikan masalah nyata untuk diselesaikan karena siswa memiliki buku penunjang sehingga siswa sudah bisa membaca sendiri dirumah. Setiap akhir pertemuan guru selalu menyampaikan materi yang akan dipelajaari selanjutnya dan siswa diminta membaca ataupun mencari referensi sendiri dirumah. Hal ini, menjadikan siswa lebih siap untuk menghadapi pembelajaran. Kelebihan lain adalah pada LKPD yang telah dibuat adalah peneliti mendesain sedemikian rupa agar siswa mampu mengidentifikasikan sendiri informasi yang diperolah. Hal ini bertjuan untuk melatih siswa agar dapat menyajikan informasiinformasi yang relevan ataupun data-data yang diperlukan saja untuk menyelesaikan masalah secara lebih efektif dan efisien.

\section{REFERENSI}

Baker, Courtney, Terrie Galanti, and Sara Birkhead. 2017. "Reasonable and Realistic." 439-46.

Chamberlin, S. A., \& Moon, S. 2005. "Model-Eliciting Activities: An Introduction to Gifted Education.” Journal of Secondary Gifted Education XVII(1):37-47.

Chan, E. C. M. 2008. Using Model-Eliciting Activities for Primary Mathematics Classrooms. Vol. 11.

Fatmawati, H., Mardiyana, M., \& Triyanto, T. 2014. "Analisis Berpikir Kritis Siswa Dalam Pemecahan Masalah Matematika Pada Materi Lingkaran.” Jurnal Pembelajaran Matematika 2(9):911-22. doi: 10.31227/osf.io/wsza9.

Firdaus, F., Kailani, I., Bakar, M. N. B., \& Bakry, B. 2015. "Developing Critical Thinking Skills of Students in Mathematics Learning. Journal of Education and Learning." Journal of Education and Learning 9(3):226-236.

Frank, B., Kaupp, J., \& Chen, A. 2013. "Investigating the Impact of Model Eliciting Activities on 
Pengembangan Perangkat Pembelajaran Matematika Berbasis Model Eliciting Activities (MEAs) untuk Meningkatkan

Development of Critical Thinking." Proceedings of the Canadian Engineering Education Association (CEEA).

Handajani, S., \& Pratiwi, H. Mardiyana. 2018. The 21st Century Skills with Model Eliciting.

Khalid, F. S., Irwan, J. M., Ibrahim, M. W., Othman, N., \& Shahidan, S. 2018. "Performance of Plastic Wastes in Fiber-Reinforced Concrete Beams." Construction and Building Materials 451-64.

Lesh, R. E., \& Doerr, H. M. 2003. Beyond Constructivism: Models and Modeling Perspectives on Mathematics Problem Solving, Learning, and Teaching. Lawrence Erlbaum Associates Publishers.

Meisya, S., Suhandri, S., \& Nufus, H. 2018. "Pengembangan Lembar Kerja Siswa Berbasis Model-

Eliciting Activities Untuk Memfasilitasi Kemampuan Komunikasi Matematis Siswa Sekolah Menengah Pertama." Journal for Research in Mathematics Learning 1(1.

Nio, Tan Hian, Y. L. Sukestiyarno, and Budi Waluya. 2017. "Study on Critical Thinking Skills Basic." 4(1):54-70.

Nurlaili, N., \& Muhartono, R. 2017. “Peran Perempuan Nelayan Dalam Usaha Perikanan Tangkap Dan Peningkatan Ekonomi Rumah Tangga Pesisir Teluk Jakarta.” Jurnal Sosial Ekonomi Kelautan Dan Perikanan 12(2):203-212.

Plomp, T. dan Nieveen, N. 2013. "Educational Design Research: An Introduction. Enschede: SLO.” Netherlands Institute for Curriculum Development.

Prastowo, A. 2011. Panduan Kreatif Membuat Bahan Ajar Inovatif.

Purwanto, M. N. 2009. Prinsip-Prinsip Dan Teknik Evaluasi Pengajaran. Bandung: Tri Remaja Rosdakarya.

Richard, C., Jensen, I., \& Guttmann, A. J. 2003. "Scaling Function for Self-Avoiding Polygons.” ArXiv Preprint Cond-Mat/0302513.

Riduwan, M. B. A. 2005. Belajar Mudah Penelitian. Bandung: Perpustakaan Nasional RI: Katalog Dalam Penerbitan (KDT).

Rostari, Riren, Irwan Irwan, and Yulkifli Yulkifli. 2018. "LKPD Development On MEAs BasedApproach to Improve the Mathematical Representation Ability of Grade X Students." International Journal of Research in Counseling and Education 1(1):27. doi: 10.24036/0010za0002.

Sadam, A., Parida, S., Padol, A. R., Verma, A. D., Baba, N. A., Khuman, W. M., ... \& Sarkar, S. N. 2017. "Study of Lysophosphatidic Acid Receptors (LPARs) in Buffalo Uterus Demonstrated Upregulation of LPAR1 and LPAR6 in Early Pregnancy." Theriogenology.

Sumarmo, U., Hidayat, W., Zukarnaen, R., Hamidah, M., \& Sariningsih, R. 2012. "Kemampuan Dan Disposisi Berpikir Logis, Kritis, Dan Kreatif Matematik (Eksperimen Terhadap Siswa Sma Menggunakan Pembelajaran Berbasis Masalah Dan Strategi Think-Talk-Write).” Jurnal Pengajaran MIPA 17(1):17-33.

Trianto, M. P. 2009. Mendesain Model Pembelajaran Inovatif-Progresif. Jakarta: Kencana.

Turmudi, T., Hidayat, A. S., Prabawanto, S., \& Jupri, A. 2014. "PEngembangan Pembelajaran 
Matematika Dengan Pemodelan (Mathematical Modeling) Berbasis Realistik Untuk Mahasiswa.” Jurnal Pengajaran MIPA 19(1):1-18.

Wafiqoh, R., Darmawijoyo, D., \& Hartono, Y. 2016. "LKS Berbasis Model Eliciting Activities Untuk Mengetahui Kemampuan Pemecahan Masalah Matematika Di Kelas VIII.” Jurnal Elemen 2(1):39-55.

Wardawati, P. D., Irwan, I., \& Efendi, J. 2018. "LKPD Development Practicality on MEAs BasedApproach In Improving Mathematical Communication Ability Of Grade X Students." International Journal of Research in Counseling and Education 83-87.

Wulandari R., Susanti, E., \& Santoso, B. 2018. Pengembangan Lembar Kerja Peserta Didik (LKPD) Menggunakan Model Eliciting Activities (MEAS) Pada Materi SPLTV (D). Doctoral dissertation, Sriwijaya University.

Yulianti, D. E., Wuryanto, W., \& Darmo, D. 2013. "Keefektifan Model-Eliciting Activities Pada Kemampuan Penalaran Dan Disposisi Matematis Siswa." Unnes Journal of Mathematics Education.

Zulkarnaen, R. 2018. "Why Is Mathematical Modeling so Difficult for Students?” AIP Publishing LLC Vol. 2021, 